\title{
Effects of Scarification and Gibberellic Acid on Germination of Congo Watermelon Seed ${ }^{1}$
}

\author{
Agripino Pérez López
}

\section{INTRODUCTION}

Watermelon (Citrullus vulgaris L.) is gaining great commercial importance in Puerto Rico because it can be grown during practically the entire year. This makes possible the production of watermelons for the winter markets when the competition with fruit produced in the Temperate Zone countries is at a minimum.

At present the introduction of seedless watermelon varieties appears to be promising since they are doing very well under our conditions. Because of the high cost of the seed of the seedless watermelon, germination studies are being performed in an attempt to insure optimum utilization of the seed available.

The work of Zielinski $(3),{ }^{3}$ who found that notching cherry seed increased germination, and of Paine (1), who reported that the germination of hop seed might be more than doubled by removal of the operculum, and the studies reported for different economic crops by Wittwer and Bukovac (2) suggested that scarification and gibberellic acid might hasten and increase watermelon seed germination. This work was therefore undertaken to determine the usefulness of scarification and gibberellic acid in the germination of Congo watermelon seed.

\section{MATERIALS AND METHODS}

The seed were treated in the following manner:

\section{SCARIFICATION TREATMENT}

One hundred and twenty seed were used for each treatment of those shown in figure 1. A file was gently passed over each individual seed from 5 to 10 times.

\section{GIBBERELLIC ACID TREATMENTS}

Each group of 120 seed that received the scarification treatment was divided into three groups of 10 seed replicated 4 times for treatment with gibberellic acid. The seed not treated with gibberellic acid were not soaked

1 Contribution from the Isabela Substation, Isabela, P.R.

${ }^{2}$ Research Assistant in Horticulture, Agricultural Experiment Station, University of Puerto Rico, Río Piedras, P.R.

3 Italic numbers in parentheses refer to Literature Cited, p. 187. 
in water, but the other two groups were soaked for 52 hours in water containing 50 and 100 p.p.m. (parts per million) of the acid.

The seed were sown on previously fumigated metal flats containing a mixture of soil of the Coto sandy clay type and filter-press cake (cachaza) at the ratio of 1 to 1 . The sown flats were exposed in the open.

The seed germination was counted $7,8,10$, and 14 days after sowing.

\section{RESULTS}

\section{SEVEN DAYS AFTER SOWING}

\section{Scarification Treatments}

None of the scarification treatments was statistically superior to the check. These results were found during all the four germination countings. This indicates that it does not pay to scarify the seed before sowing them.
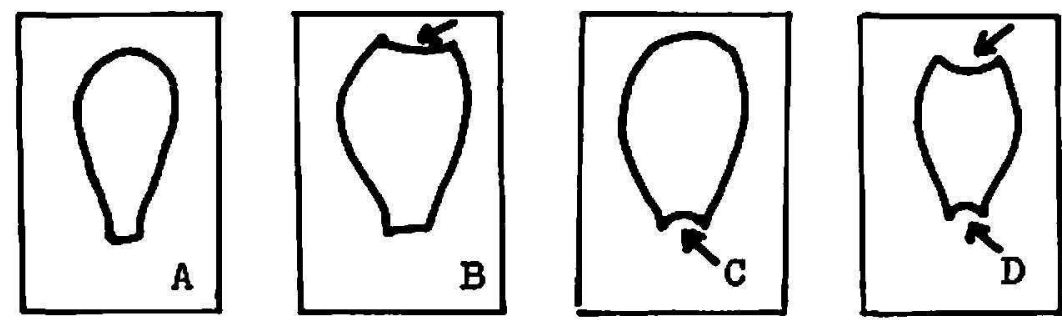

FIG. 1.-Diagram illustrating the watermelon seed and its treatments: $A$, Check; no scarification. B, Scarification of the wider end of the seed. C, Scarification of the narrower end of the seed. D, Scarification of both ends of the seed. The arrows point to the scarified ends of the seed enlarged two times.

\section{Gibberellic Acid Treatments}

The increase of gibberellic acid from 0 to 100 p.p.m. reduced the germination of Congo watermelon seed in a highly significant way. The reduction in germination of the seed treated with 50 p.p.m. of the acid was significant only at the 5-percent level. The mean percentages of seed germinated for the 0,50 , and 100 p.p.m. of gibberellic acid were $62.50,55.00$, and 40.00, respectively (table 1 and figure 2).

The standard errors and least differences required for significance between mean percentage of germinated seed under gibberellic acid treatments are shown in the following tabulation:

\section{Comparison}

Least significant difference between highest and lowest means

Least significant difference between 2 adjacents

Standard error 4.08 with 16 d.f. 5-percent level

14.16

11.75 1-percent level

18.03

15.79 


\section{EIGHT DAYS AFTER SOWING}

\section{Gibberellic Acid Treatments}

Table 1 shows the mean percentages for seed germination. Figure 2 also shows graphically the differences between treatments. Seed receiving 0 and 50 p.p.m. of gibberellic acid germinated highly significantly more than those receiving 100 p.p.m. of the chemical. The difference between 0 and 50 p.p.m. was significant only at the 5 -percent level. The mean percentages of germination for the seed receiving 0,50 , and 100 p.p.m. of gibberellic acid were $77.50,67.50$, and 53.13 , respectively.

The standard errors and least differences required for significance be-

TABLE 1.-The effects of $s$ concentrations of gibberellic acid on the mean germination percentage of Congo watermelon seed $7,8,10$, and 14 days after being sown

\begin{tabular}{c|c|c|c|c|c}
\hline $\begin{array}{c}\text { concentrations of } \\
\text { sibberellic acid } \\
\text { (p.p.m.) }\end{array}$ & \multicolumn{3}{|c|}{ Germinated seed after number of days indicated } & Mean \\
\cline { 2 - 4 } & 7 & 8 & 10 & 14 & \\
\hline 0 & 62.50 & 77.50 & 78.13 & 76.88 & 74.38 \\
50 & 55.00 & 67.50 & 70.00 & 70.63 & 65.78 \\
100 & 40.00 & 53.13 & 53.75 & 55.63 & 50.63 \\
\hline \multirow{2}{*}{ Mean } & 53.33 & 66.04 & 67.29 & 67.71 & 63.59 \\
\hline
\end{tabular}

tween mean percentage of germinated seed of those treated with gibberellic acid are shown in the following tabulation:

\section{Comparison}

Least significant difference between highest and lowest means

Least significant difference between 2 adjacents

Standard error 3.65 with 16 d.f. 5-percent level

12.67

10.51 1-percert level

16.13

14.13

\section{TEN DAYS AFTER SOWING}

\section{Gibberellic Acid Treatments}

The mean percentages of germinated seed are presented in table 1 and figure 2. For the concentrations of 0,50 , and 100 p.p.m. of gibberellic acid the germination percentages were $78.13,70.00$, and 53.75 , respectively. The means for 0 and 50 p.p.m. of gibberellic acid were highly significantly greater than the mean for 100 p.p.m. of the chemical. The difference between 0 and 50 p.p.m. was not significant. In this case, as in the 7- and 8-day samples after sowing the seed, the gibberellic acid application suppressed the germi- 
nation of the Congo watermelon seed. The suppression increased as the concentration of the gibberellic acid increased.

The standard errors and least differences required for significance between

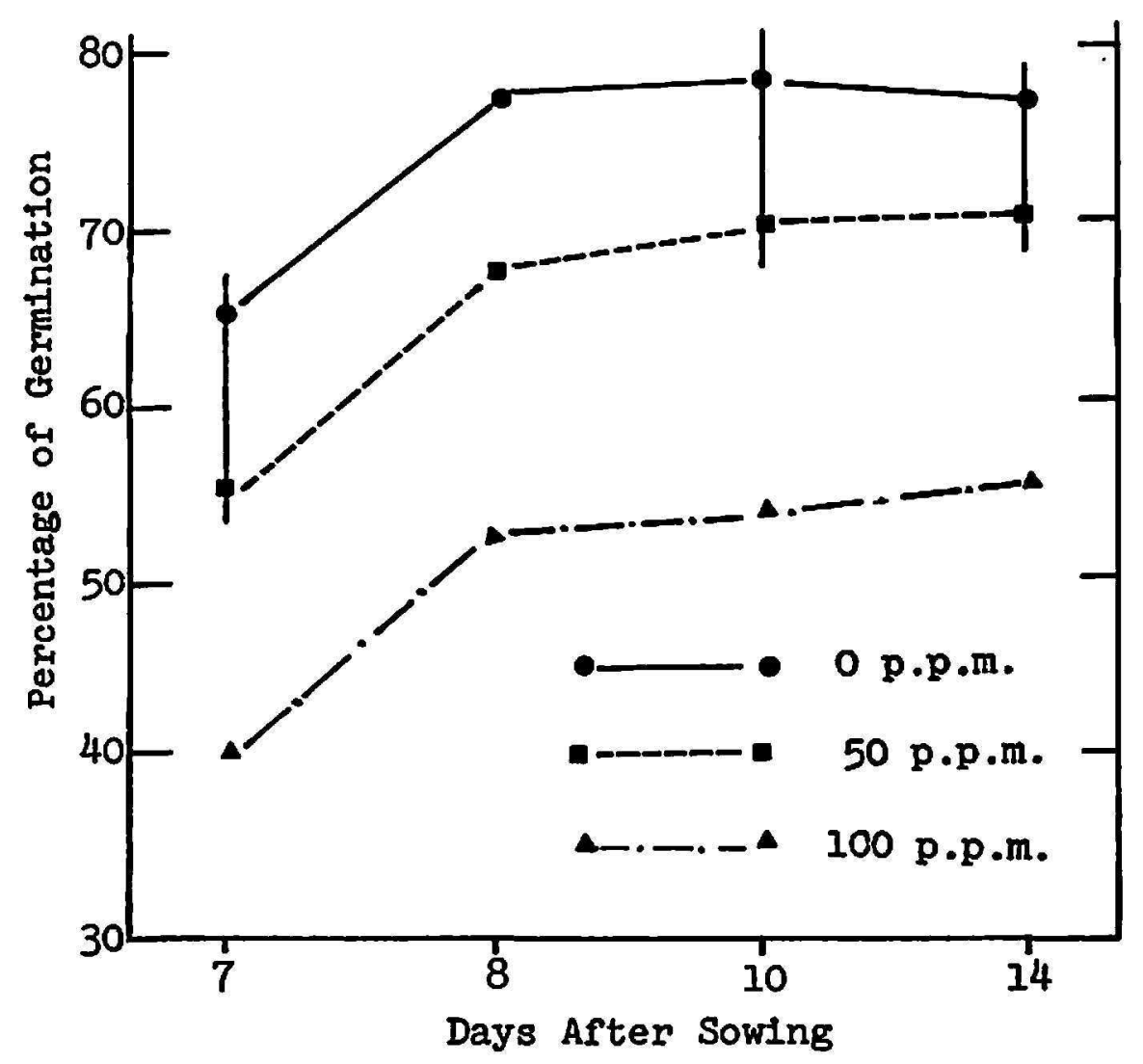

FIG. 2.-The effects of 3 concentrations of gibberellic acid on the germination of Congo watermelon seed. Means enclosed by the same vertical line are not significant at the 5-percent level; means not enclosed by the same vertical line are significant at the 5-percent level or more.

mean percentage of germinated seeds under gibberellic acid treatment are shown in the following tabulation:

\section{Comparison}

Least significant difference between highest and lowest means

Least significant difference between 2 adjacents

Standard error 3.36 with 16 d.f.

$$
\text { 5-pereent lecel }
$$$$
11.66
$$

9.68 1-percent legel

14.85

13.0

\section{FOURTEEN DAYS AFTER SOWING}

Gibberellic Acid Treatments

The means for the gibberellic acid-treated seed (table 1 and figure 2) were $76.88,70.63$, and 55.63 for the 0,50 , and 100 p.p.m., respectively. In the treatments receiving 0 and 50 p.p.m. of gibberellic acid the germination 
percentage was highly significantly greater than in those receiving 100 p.p.m. The difference between 0 and 50 p.p.m. of gibberellic acid was not significant. On this date, as on the previous three, the gibberellic acid reduced the germination. This reduction tended to increase as the concentration of the chemical increased.

The standard errors and least differences required for significance between mean percentage of germinated seed of those treated with gibberellic acid are shown in the following tabulation:

\section{Comparison}

Least significant difference between highest and lowest means

Least significant difference between 2 adjacents

Standard error 3.20 with 16 d.f. 5-percent level

11.10

9.22 1-percent lesel

14.14

12.38

\section{DISCUSSION}

This study demonstrated that none of the scarification treatments was statistically superior to the check. This same result was found during all the four germination countings. This tends to indicate that there is no need to scarify Congo watermelon seed because the humidity enters readily through the seedcoats after sowing.

The experiment also showed that gibberellic acid should not be used to promote the germination of watermelon seed, at least with Congo, the variety used in this study, because it reduces germination. This reduction in germination was increased as the concentration of the acid increased, irrespective of the scarification treatments given to the seed. As had been reported (2), and in accordance with the results of this study, gibberellic acid may promote the germination of seed that require a dormancy period, but not of those which do not require it, such as the watermelon.

The interaction between scarification and gibberellic acid was not significant. This indicates that there is no need to scarify the seed and then soak them in a solution of the acid because this acid reduces germination of scarified as well as of nonscarified seed.

\section{SUMMARY}

The effects of scarification and the use of gibberellic acid were studied on the germination of Congo watermelon seed observed in the germinating flats $7,8,10$, and 14 days after sowing. Observations were made on the percentage of germinated seeds. The major results were as follows:

1. Gibberellic acid at concentrations of 50 and 100 p.p.m. considerably reduced the germination of the watermelon seed. This effect was observed on all four dates that the germination was counted. The reduction in germination increased as the concentration of the gibberellic acid increased. 
2. None of the scarification treatments was statistically superior to the check. This was found at all four germination countings.

\section{RESUMEN}

Se estudió el efecto de la escarificación y el uso del ácido giberélico en cuanto a la germinación de la semilla de sandía. Los resultados fueron los siguientes:

1. El ácido giberélico, en concentración de 50 y 100 p.p.m. (partes por millón), redujo considerablemente el porcentaje de germinación de la semilla de sandía. Este efecto se observó durante cada una de las cuatro fechas en que se contaron las semillas germinadas. La reducción en la germinación aumentó al aumentar la concentración del ácido giberélico.

2. Ninguno de los tratamientos usados para escarificar la semilla demostró ser estadísticamente superior al testigo. Este efecto se observó en cada una de las cuatro fechas en que se contaron las semillas germinadas.

\section{LITERATURE CITED}

1. Paine, J., The Treatment of Hop Seed to Improve Germination, East Malling Res. Exp. Sta., England, Ann. Rep. 139-40, 1950.

2. Wittwer, S. H., and Bukovac, M. J., The effects of gibberellin on economic crops, Econ. Bot., 12 213-55, 1958.

3. Zielinski, Quentin B., Some factors affecting seed germination in sweet cherries, Proc. Amer. Soc. Hort. Sci. 72 123-9, 1958. 